\title{
Sosialisasi Penggunaan Pembersih Tangan (Handsanitizer) Yang Efektif Dalam Upaya Memenuhi Standart Who Dan Protokol Kesehatan Sesuai Dengan UU No.6 Tahun 2018 Tentang Karantina Kesehatan Di Muhammadiyah Kramat Jati, Jakarta Timur
}

Marjan Miharja, Erwin Syahruddin, Bionda Johan Anggara, Johan, Gugus Atmoko, Abdillah Umar Lubis, M. Khoerul Anam \& Gerry Lesmana

Sekolah Tinggi Ilmu Hukum IBLAM

\begin{abstract}
WHO determined COVID-19 as a pandemic on March 9, 2020, which is the strongest push for this community service program to be carried out. WHO has published guidance on adjusting the MFIs while managing the risk of a spike in case numbers. WHO publishes guidance on adapting to LKMS, while still managing the risk of a re-increase in the number of cases. A series of measures was developed to help provide guidance to countries in adapting public health measures to various contexts and this provides consideration for decision makers. In connection with the policy of controlling infectious disease outbreaks, Indonesia has Law Number 4 of 1984 concerning Communicable Disease Outbreaks, Government Regulation Number 40 of 1991 concerning Management of Contagious Disease Outbreaks, and Regulation of the Minister of Health Number 1501 / Menkes / Per / X / 2010 concerning Certain Types of Infectious Diseases That Can Cause Outbreaks and Countermeasures. Including various policies to deal with the Covid-19 pandemic issued by the government. One of them is the Large-Scale Social Restrictions or PSBB at the end of March. Citing Article 1 paragraph 11 of Law (UU) Number 6 of 2018 concerning Health Quarantine, PSBB is a limitation of certain activities of residents in an area suspected of being infected with a disease and / or contamination in such a way as to prevent the possibility of spreading disease or contamination. The policy covers at least school and work vacations, restrictions on religious activities and restrictions on activities in public places or facilities, including the socialization of washing hands using hand sanitizer which can be done in certain situations where soap and clean water are not available. For the results to be effective, the hand sanitizer used should contain at least $60 \%$ alcohol. This step is a necessity in order to prevent Covid-19 from becoming more widespread. The goal to be achieved from the socialization of good and correct hand washing is to understand the procedures, and be able to practice how to wash hands properly and correctly. It is hoped that in this socialization there will be a change in behavior in the community in washing hands as often as possible properly and correctly.
\end{abstract}

Keywords Cairan handsanitizer aman ramah lingkungan dan desain produk

\section{Pendahuluan}

WHO menentapkan COVID-19 sebagai pandemi pada tanggal 9 Maret 2020 yang mana hal ini merupakan dorongan terkuat program pengabdian masyarakat ini dilakukan. Banyak sektor terkena dengan adanya pandemic ini dari sektor ekonomi, sosial, dan pendidikan juga ikut terdampak akibat pandemi COVID-19, termasuk menular kenegara Indonesia. Masyarakat hanya bisa melakukan pencegahan pemutusan rantai penyebaran virus dengan memahami dan melaksanakan protokol kesehatan yang dianjurkan oleh WHO dan pemerintah Indonesia. Pemerintah lewat beberapa aturan dan media menganjurkan untuk selalu menerapkan pola hidup bersih dan tetap dirumah dengan

Published by:

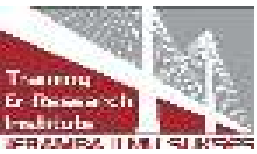


selalu menjaga kesehhatan. Indonesia dan negara-negara di seluruh dunia telah menerapkan serangkaian langkah-langkah kesehatan masyarakat dan sosial (LKMS), seperti pembatasan pergerakan, penutupan sekolah atau tempat kerja, dan pelarangan perjalanan mancanegara. Seiring berubahnya situasi epidemiologi penyakit ini di wilayah masing-masing, negara-negara akan menyesuaikan (melonggarkan atau memberlakukan kembali) langkah-langkah ini sesuai intensitas penularan.

WHO telah menerbitkan panduan tentang penyesuaian LKMS sambil mengelola risiko lonjakan kembali jumlah kasus. WHO menerbitkan panduan tentang penyesuaian LKMS, dengan tetap mengelola risiko peningkatan kembali jumlah kasus. Serangkaian langkahlangkah dikembangkan guna membantu memberikan panduan kepada negara-negara dalam menyesuaikan langkah-langkah kesehatan masyarakat dalam berbagai konteks dan ini memberikan pertimbangan-pertimbangan bagi pengambil keputusan. Berkaitan dengan kebijakan penanggulangan wabah penyakit menular, Indonesia telah memiliki Undang-Undang Nomor 4 Tahun 1984 tentang Wabah Penyakit Menular, Peraturan Pemerintah Nomor 40 Tahun 1991 tentang Penangulangan Wabah Penyakit Menular, dan Peraturan Menteri Kesehatan Nomor 1501/Menkes/Per/X/2010 tentang Jenis Penyakit Menular Tertentu Yang Dapat Menimbulkan Wabah dan Upaya Penanggulangan. Termasuk berbagai kebijakan untuk menanggulangi pandemi Covid-19 dikeluarkan pemerintah. Salah satunya Pembatasan Sosial Berskala Besar atau PSBB pada akhir Maret lalu. Mengutip Pasal 1 ayat 11 Undang-Undang (UU) Nomor 6 Tahun 2018 tentang Karantina Kesehatan, PSBB adalah pembatasan kegiatan tertentu penduduk dalam suatu wilayah yang diduga terinfeksi penyakit dan/atau terkontaminasi sedemikian rupa untuk mencegah kemungkinan penyebaran penyakit atau kontaminasi. Kebijakan tersebut paling sedikit meliputi peliburan sekolah dan tempat kerja, pembatasan kegiatan keagamaan dan pembatasan kegiatan di tempat atau fasilitas umum termasuk sosialisasi mencuci tangan menggunakan cairan pembersih tangan yang dapat dilakukan dalam situasi tertentu dimana sabun dan air bersih tidak tersedia. Agar hasilnya efektif, cairan pembersih tangan yang digunakan hendaknya mengandung alkohol dengan kadar minimal $60 \%$. Langkah ini adalah sebuah keniscayaan guna menghadang agar covid-19 tak makin meluas. Tujuan yang ingin dicapai dari sosialisasi cuci tangan yang baik dan benar dapat memahami tata cara, dan dapat mempraktikkan bagaimana cuci tangan yang baik dan benar. Diharapkan dalam sosialisasi ini terdapat perubahan perilaku di masyarakat dalam mencuci tangan sesering mungkin dengan baik dan benar.

Adapun rumusan masalah adalah (a) Bagaimana membuat cairan Handsanitizer yang aman serta ramah lingkungan yang direkomendasikan oleh BPOM dan Organisasi Kesehatan Dunia (WHO) untuk membantu masyarakat menghadapi era New Normal? (b) Bagaimana melakukan sosialisasi cara mencuci tangan yang efektif dengan menggunakan Handsanitizer sesuai dengan standart WHO?

\section{Solusi Permasalahan}

Dengan permasalahan yang ada yaitu mengenai produksi pembuatan cairan Handsanitizer dan desain produk dan juga mengenai waktu serta bahan bahan dasar yang susah kami apatkan, maka kami mencoba berkoordinasi dengan pihak Mitra 1 PWPM DKI Jakarta mengenai jadwal yang telah kami susun untuk kegiatan PKM ini, solusi yang kami dapatkan, sebagai berikut: (a) Dengan Kepakaran yang dimiliki Mitra 1 PWPM DKI Jakarta, kami dapat membuat Handsanitizer dan desain produk yang aman dan ramah

Published by:

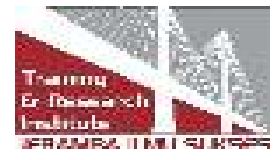


lingkungan; (b) Berkoordinasi dengan Mitra kami PCM Kramat Jati dan PWPM DKI Jakarta Koordinasi yang dimaksud guna menyesuaikan dengan waktu yang mitra miliki agar semua jadwal dapat berjalan sesuai rencana dan kami juga dapat segera menyelesaikan tugas ini sesuai waktu yang telah ketua PKM berikan; (c) Dari beberapa solusi diatas ada target luaran yang akan kami lakukan yaitu dengan menginfokan pada masyarakat baik bahwa kami sebagai mahasiswa juga dapat memberikan sumbangsih kepada negara dan masyarakat Indonesia sesuai dengan kemampuan kami sebagai mahasiswa. Melalui jurnal yang akan kami terbitkan di JNPM (Jurnal Nasional Pengabdian Masyarakat) http:/journal jis-institute.org/index.php/jnpm, Kegiatan PKM yang akan kami info dikoran Republika dan Sindo Online, Kegiatan PKM yang akan kami upload di link channel youtube Kampus STIH IBLAM, Laporan harian kegiatan akan kami serahkan dalam bentuk jurnal pada ketua PKM dan laporan akhir kegiatan PKM Yang akan kami lakukan dengan mengadakan Seminar laporan akhir kegiatan PKM di tempat domisili Mitra kami PCM Kramat Jati, Jakarta Timur, DKI Jakarta.

\section{Metode Pelaksanaan}

Metode pelaksanaan untuk mencapai tujuan dari Kegiatan Pengabdian Kepada Masyarakat ini dalam mengatasi masalah masyarakat untuk menghadapi kondisi new normal yang dilakukan oleh Tim Pengabdi adalah menyumbang Produk Handsanitaizer dengan pengemasan menarik yang telah kami buat bersama mitra PWPM DKI Jakarta yang nantinya oleh mitra 2 kami yaitu PCM Kramat Jati akan dibantu untuk dibagikan kepada masyarakat sekitar mitra kami berdomisili.

Permasalahan dari kedua belah pihak dalam proses pembuatan Handsanitaizer dan desain packing produk hampir sama yaitu WAKTU, maka solusi yang kami hadirkan dalam dalam pelaksanaan kegiatan ini ada beberapa metode, sebagai berikut :

\begin{tabular}{|c|c|c|c|}
\hline NO. & PERMASALAHAN & $\begin{array}{c}\text { SOLUSI } \\
\text { PERMASALAHAN }\end{array}$ & $\begin{array}{c}\text { METODE } \\
\text { PELAKSANAAN }\end{array}$ \\
\hline 1. & $\begin{array}{l}\text { Cara membuat cairan } \\
\text { Handsdanitizer yang } \\
\text { aman dan ramah } \\
\text { lingkungan }\end{array}$ & $\begin{array}{l}\text { Dari permasalahan yang ada } \\
\text { kami mencoba berkoordinasi } \\
\text { dengan mitra kami, dan kami } \\
\text { mendapatkan informasi cara } \\
\text { membuat desinfektan yang } \\
\text { aman dan ramah lingkungan, } \\
\text { dengan bahan bahan dan } \\
\text { komposisi yang sudah sesuai } \\
\text { standart kesehatan dan tidak } \\
\text { ada efek samping yang } \\
\text { dihasilkan. }\end{array}$ & $\begin{array}{l}\text { Dari bahan bahan } \\
\text { yang telah ada kami } \\
\text { melakukan } \\
\text { pencampuran } \\
\text { bahan tersebut } \\
\text { dengan komposisi } \\
\text { secukupnya sesuai } \\
\text { takaran dari } \\
\text { beberapa liter } \\
\text { Handsanitaizer } \\
\text { yang akan dibuat. }\end{array}$ \\
\hline 2. & $\begin{array}{l}\text { Desain produk } \\
\text { Handsanitaizer }\end{array}$ & $\begin{array}{l}\text { Dari permasalahan yang ada } \\
\text { kami mencoba berkoordinasi } \\
\text { dengan mitra kami untuk } \\
\text { mendapatkan informasi } \\
\text { tentang kadar alcohol standart }\end{array}$ & $\begin{array}{l}\text { Dari desain standart } \\
\text { pengemasan } \\
\text { produk yang } \\
\text { beredar secara } \\
\text { umum antara } 70 \%\end{array}$ \\
\hline
\end{tabular}

Published by:

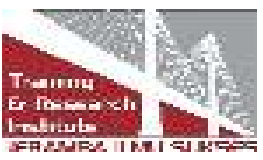




\begin{tabular}{|c|c|c|c|}
\hline & & $\begin{array}{l}\text { yang digunakan oleh mitra } \\
\text { kami. }\end{array}$ & $\begin{array}{lr}\text { dan } 75 \% \text { maka dari } \\
\text { mitra kami } \\
\text { menyepakati } & \text { kadar } \\
\text { alcohol yang harus } \\
\text { tertera di } & \text { desain } \\
\text { produk } & \text { adalah } \\
70 \% . & \end{array}$ \\
\hline 3. & $\begin{array}{l}\text { Waktu dengan mitra } \\
\text { banyak yang tidak } \\
\text { sesuai sehingga perlu } \\
\text { dikoordinasikan } \\
\text { lebih lanjut. }\end{array}$ & $\begin{array}{l}\text { Waktu adalah masalah yang } \\
\text { sangat menjadi penentu } \\
\text { akann kegiatan PKM ini, } \\
\text { maka dari itu koordinasi dan } \\
\text { menyesuaikan wakti dengan } \\
\text { mitra adalaj alan keluar dari } \\
\text { masalah ini agar semua } \\
\text { rancana tetap berjalan dengan } \\
\text { seharusnya. }\end{array}$ & $\begin{array}{l}\text { Kami mencocokan } \\
\text { jadwal kegiatan } \\
\text { kami dengan waktu } \\
\text { kosong atau waktu } \\
\text { senggang dr pihak } \\
\text { mitra Pemuda } \\
\text { muhammadiyah } \\
\text { cawang, yang } \\
\text { akhirnya program } \\
\text { kami dapat berjalan } \\
\text { sesuai rencana yang } \\
\text { sudah kami buat } \\
\text { tanpa harus } \\
\text { mengurangi jadwal } \\
\text { dari PKM. }\end{array}$ \\
\hline
\end{tabular}

\section{Pelaksanaan Kegiatan}

Tahapan awal dari kegiatan ini adalah kami melakukan observavi ke mitra dengan dengan beberapa kegiatan, sbb :

a. Kunjungan ke PCM kramat Jati dan Pemuda muhammadiyah KramatJati

b. Mendapatkan bimbingan dari PCM kramat Jati dan Pemuda muhammadiyah KramatJati tentang apa yang akan menjadi tema dalam PKM kali.

c. Membuat Handsanitizer adalah arahan dari PCM Kramat Jati dan Pemuda Muhammadiyah Kramat Jati.

d. Melakukan Baksos dilingkungan sekitar mitra berdomisili.

e. Laporan harian dan dilaporkan keketua PKM.

f. Laporan akhir Kegiatan di Muhammadiyah kramat Jati .

$>\quad$ Kegiatan Pertama / Kamis ,13 November 2020

Bimbingan PKM (Ketua PKM Dr. Marjan Miharja, S.H.,M.H.)

Pengarahan Kegiatan PKM, cara pembuatan proposal PKM dan pengenalan mitra PCM Kramat Jati dan PWPM DKI Jakarta untuk kegiatan PKM

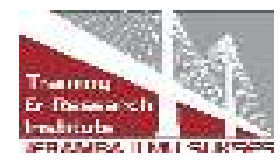




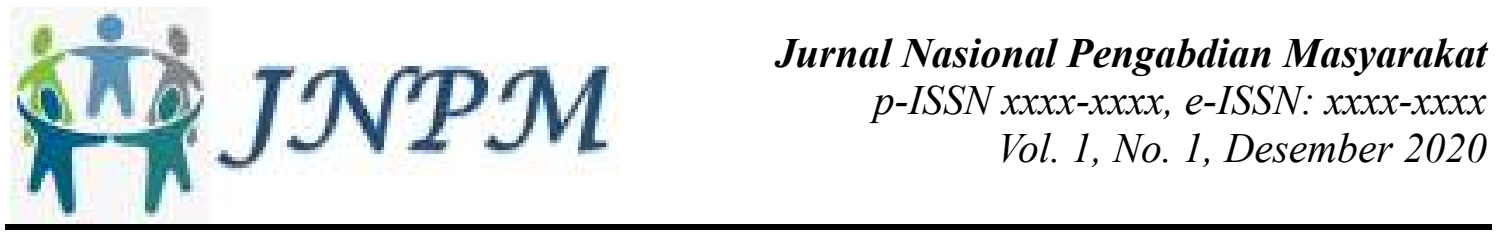

Dokumentasi :
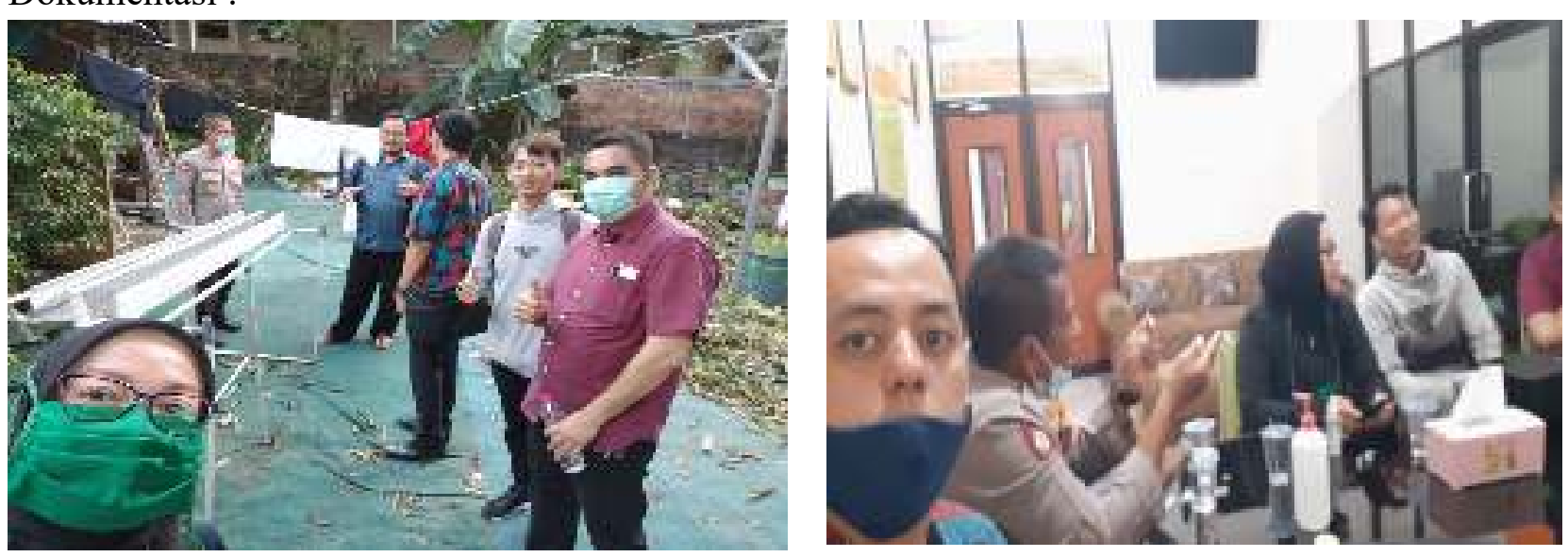

$>\quad$ Kegiatan Kedua / Senin, 16 November 2020

\section{Bimbingan PKM}

(Ketua PKM Dr. Marjan Miharja, S.H.,M.H./ Apt. Guntur S.R, S.,Si.)

Pengarahan tentang kemitraan dan produk yang dihasilkan, menjelaskan tentang luaran wajib yang akan dihasilkan.Dokumentasi :
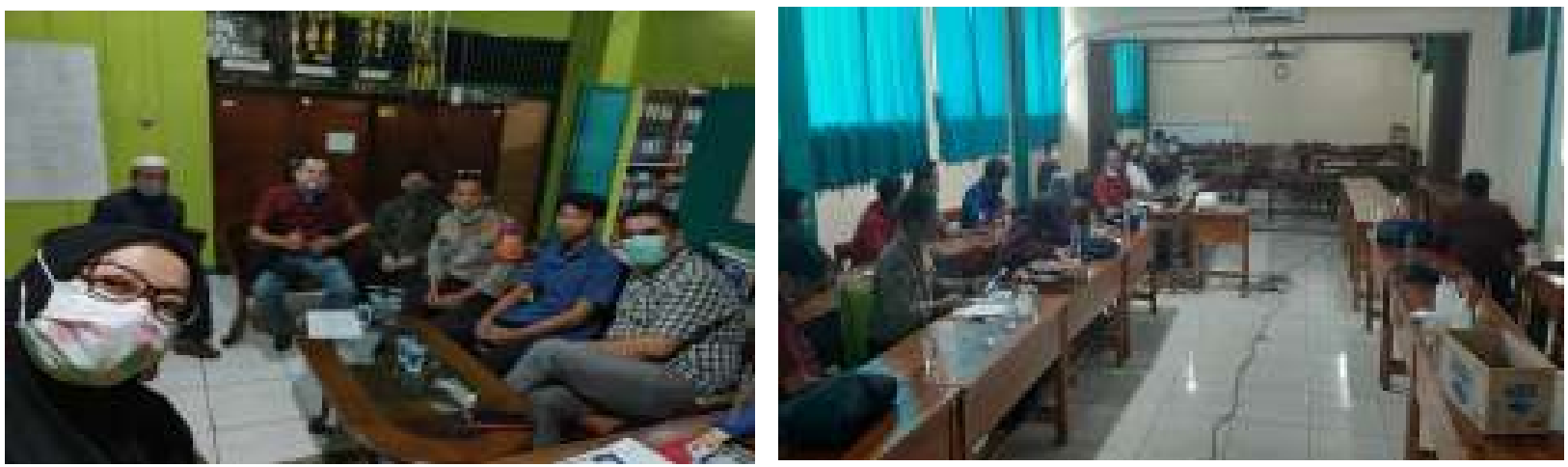

Bimbingan PKM / Senin, 23 November 2020

(Ketua PKM Dr. Marjan Miharja, S.H.,M.H./ PWPM DKI Jakarta Apt. Guntur S.R , S.,Si.)

Pengarahan tentang tahapan pembuatan Handsanitizer yang aman dan ramah lingkungan juga desain produk serta penjelasan tentang komposisi produk.

Dokumentasi :
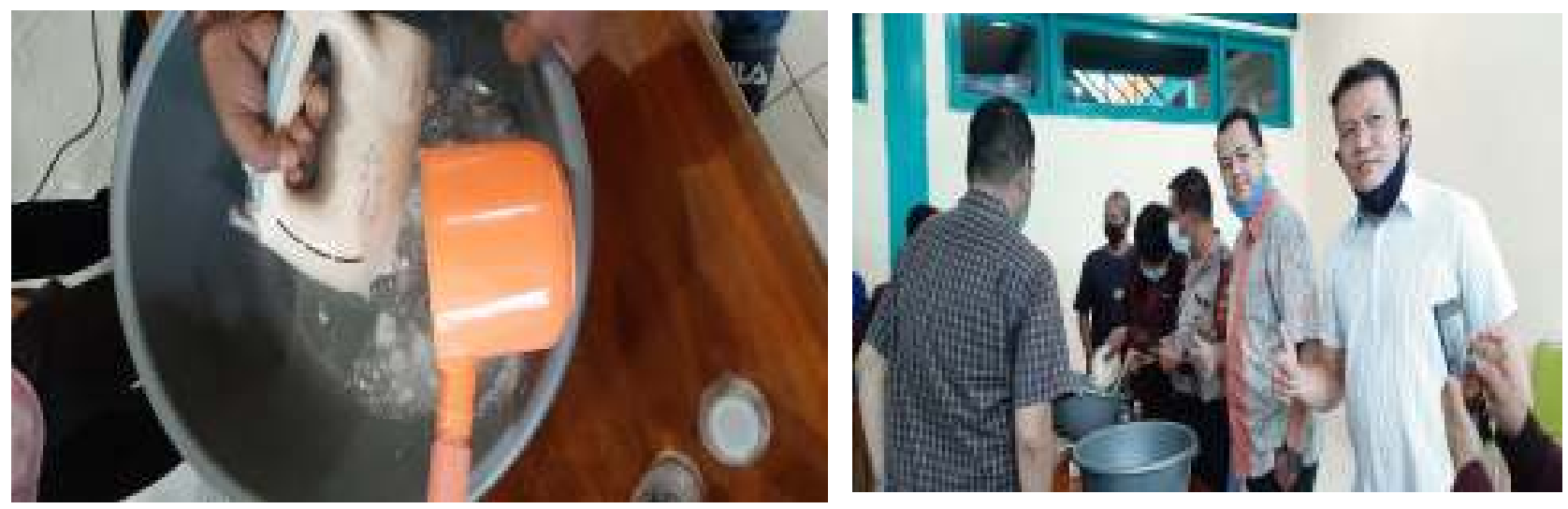

Published by:





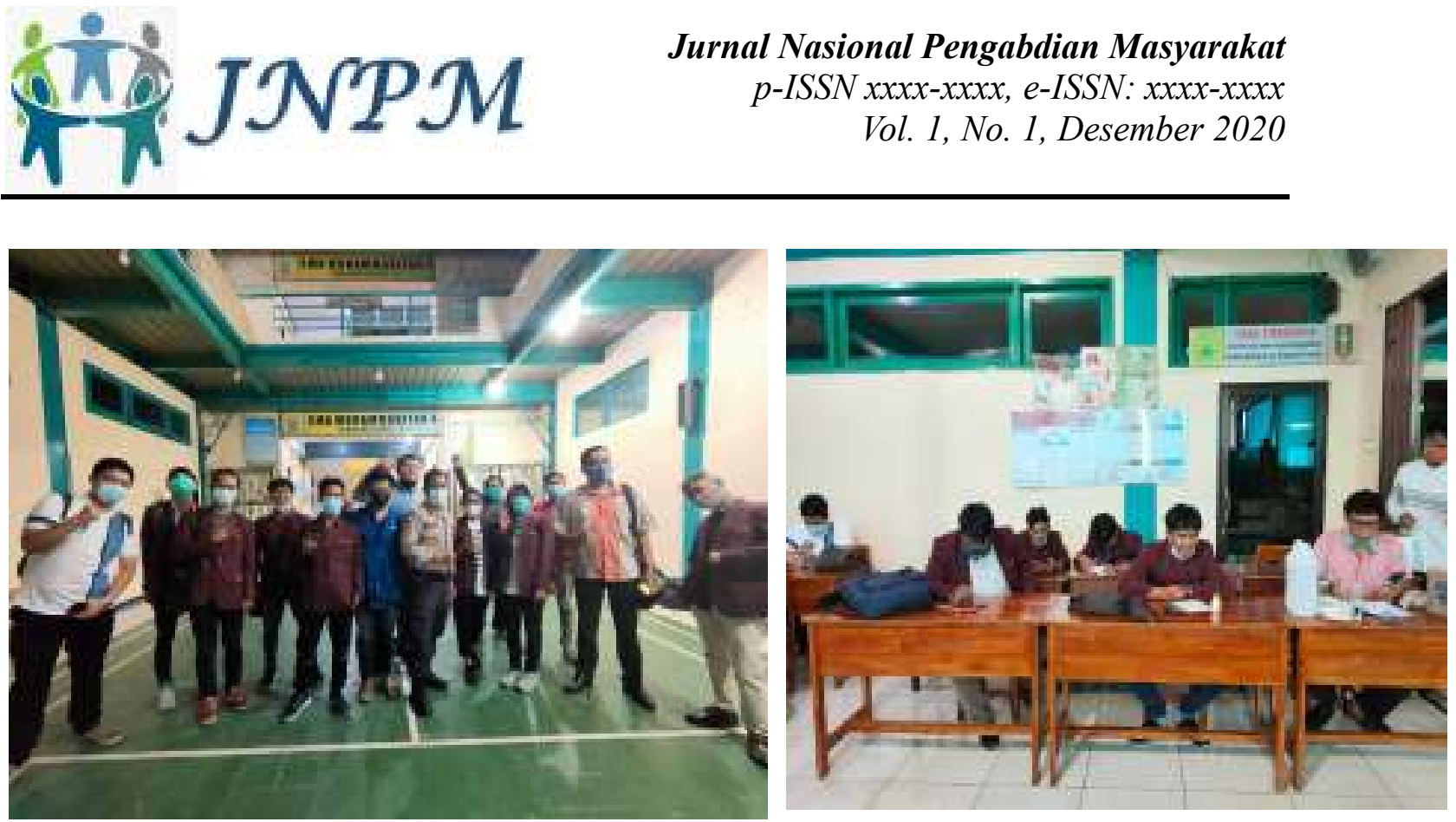

$>\quad$ Kegiatan keempat / Selasa, 24 November 2020

Pengajuan Proposal PKM / Bertempat di STIH IBLAM dan diuji oleh dosen dan Ketua PKM STIH IBLAM

\section{$>\quad$ Kegiatan Kelima / Kamis, 26 November 2020}

\section{Bimbingan Pembuatan Produk PKM}

(Ketua PWPM DKI Jakarta Apt. Guntur S.R, S.,Si.)

Pembuatan produk Handsanitizer dan desain Produk dengan kapasitas 10 liter dengan menghasilkan 170 buah botol Handsanitizer, yang akan dipandu oleh mitra PWPM DKI Jakarta.

Dokumentasi :
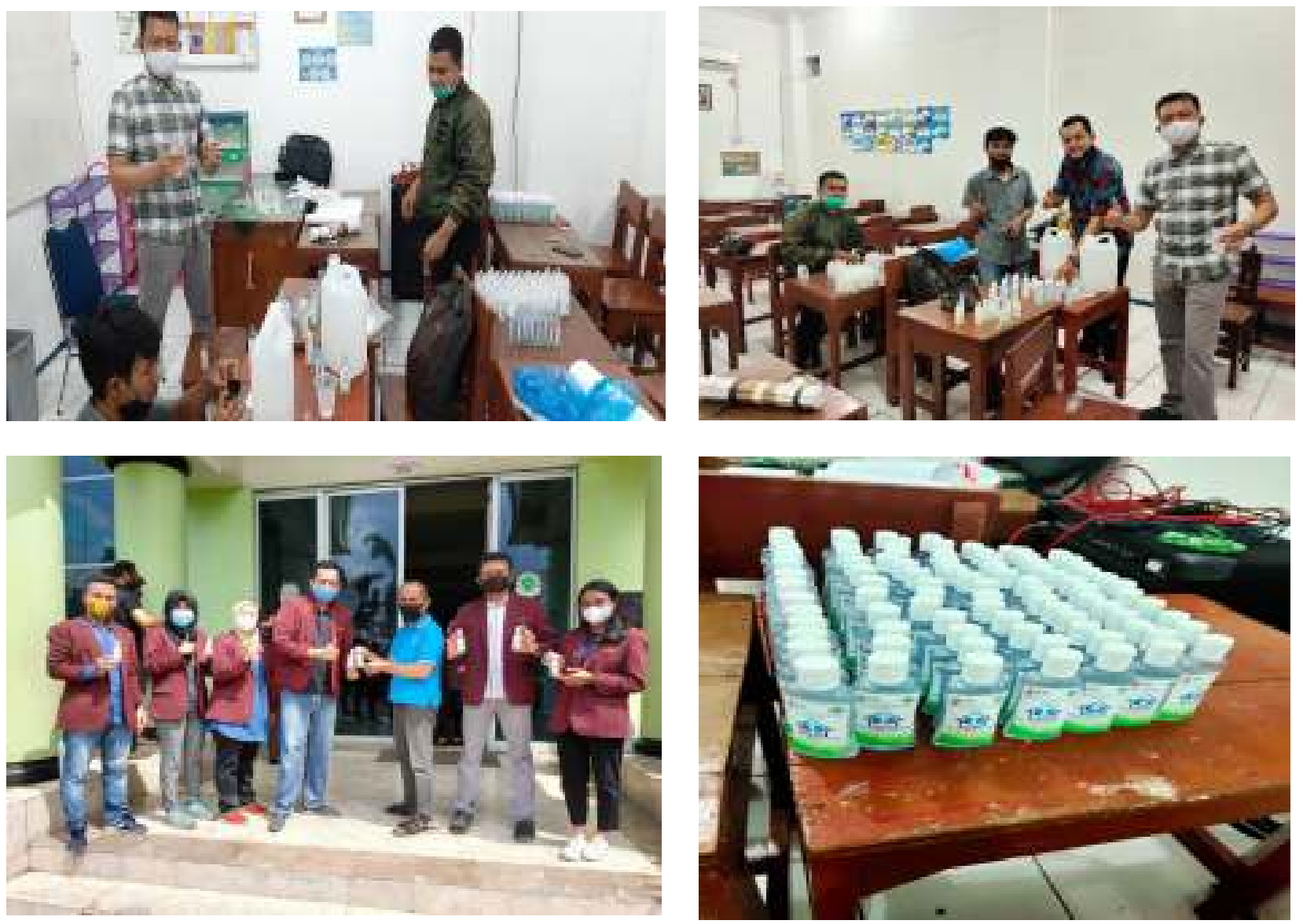
$>\quad$ Kegiatan Keenam

\section{Laporan Harian kegiatan PKM}

Laporan Harian kegiatan PKM ini akan kami buat dalam bentuk jurnal dan kami laporkan kepada Ketua PKM STIH IBLAM

\section{$>\quad$ Kegiatan Ketujuh}

\section{Seminar Laporan Akhir kegiatan PKM}

Kami akan memaparkan laporan kegiatan selama PKM di acara seminar yang akan diselenggarakan ditempat mitra kami yaitu PCM Kramat Jati, Jakarta Timur, DKI Jakarta.

\section{Kesimpulan}

Kegiatan ini kami mencoba merangkul kemitran dari PCM Kramat Jati dan Pemuda Muhammadiyah Kramat Jati Jakarta Timur guna menghasilkan produk yang bermanfaat. Produk yang akan kami hasilkan adalah Cairan Handsanitizer yang bisa digunakan untuk penetralisir wabah pandemi yang sedang terjadi saat ini dengan desain dan packing yang menarik dengan menampilkan logo IBLAM dan Logo Muhammadiyah sebagai bentuk kemitraan yang saling menguntungkan.

\section{Referensi}

Moh. Rivai Nakoe, Nur Ayini S lalu, \& Yesintha Amelia Mohamad., (2020) Perbedaan efektivitas hand-sanitizer dengan cuci tangan menggunakan sabun sebagai bentuk pencegahan COVID-19. Jambura Jurnal of Health Sciences and research, Vol. 2

Dalinama Telaumbanua. (2020) Urgensi Pembentukan Aturan Terkait Pencegahan Covid19 di Indonesia. Jurnal Pendidikan, Sosial, dan Agama., Vol. 12 No. 1

Perubahan Kedua Undang-Undang Dasar 1945, kesehatan ditegaskan sebagai bagian dari hak asasi manusia. Dalam Pasal $28 \mathrm{H}$ ayat (1) dinyatakan, bahwa: "Setiap orang berhak hidup sejahtera lahir dan batin, bertempat tinggal, dan mendapat lingkungan hidup yang baik dan sehat serta berhak memperoleh pelayanan kesehatan."

Undang-undang Nomor 36 Tahun 2014 tentang Tenaga Kesehatan namun saat ini belum ada peraturan pelaksanaan dan petunjuk teknis Undang-undang Tenaga kesehatan dan undang-undang lainnya yang mengatur tentang perlindungan hukum dan keselamatan kerja bagi Tenaga kesehatan.

Undang-Undang Nomor 6 Tahun 2018 tentang Kekarantinaan Kesehatan merupakan wewenang absolut Pemerintah Pusat.

Peraturan Menteri Kesehatan Nomor 9 Tahun 2020 tentang Pedoman Pembatasan Sosial Berskala Besar (PSBB) dalam Rangka Percepatan Penanganan Corona Virus Disease 2019 (COVID-19)

Keputusan Menteri Kesehatan Republik Indonesia Nomor HK.01.07/MENKES/413/2020 Tentang Pedoman Pencegahan Dan Pengendalian Corona Virus Disease 2019 (COVID19).

Surat Edaran Menteri Kesehatan Nomor HK.02.01.07/MENKES/413/2020 Tentang Pedoman Pencegahan Dan Pengendalian Corona Virus Disease 2019 (COVID-19)

Published by:

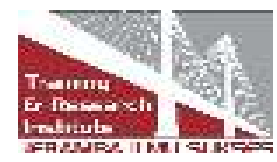




\section{Copyrights}

Copyright for this article is retained by the author(s), with first publication rights granted to the journal.

This is an open-access article distributed under the terms and conditions of the Creative Commons Attribution license (http://creativecommons.org/licenses/by/4.0/) 